\title{
RECENZJE
}

\author{
Forum Pedagogiczne \\ $10(2020) 2$ \\ Wpłynęło: 27.04.2020 \\ Zatwierdzono do druku: 24.06.2020 \\ DOI: $10.21697 / \mathrm{fp} .2020 .2 .22$
}

HENRYK MIZEREK*

Olsztyn, Polska

ORCID ID: https://orcid.org/oooo-ooo1-8674-2205

\section{Naukowe podstawy dydaktyki}

[Dietrich Benner (2020). Zarys ogólnej dydaktyki nauki. Podstawy i orientacje dla kształcenia nauczycieli, nauczania i badań edukacyjnych. Stępkowski D. (tłum.). Kraków: Oficyna Wydawnicza „Impuls”].

Dietrich Benner w książce pt. Zarys ogólnej dydaktyki nauki. Podstawy i orientacje dla kształcenia nauczycieli, nauczania i badań edukacyjnych podejmuje kwestie o kluczowym znaczeniu nie tylko dla współczesnej dydaktyki, lecz także pedagogiki jako jednej z dyscyplin nauk humanistycznych i społecznych. W centrum zainteresowań autora znalazła się dydaktyka nauki - kategoria, która w Polsce rzadko bywa przedmiotem analiz i badań pedagogicznych. Przyjęło się bowiem sądzić, że sztuka nauczania nauki może być - co najwyżej - przedmiotem zainteresowań dydaktyk szczegółowych, nie zaś dydaktyki ogólnej.

D. Benner dowodzi, że przez odwołanie się do historii myśli pedagogicznej, historii filozofii i historii nauki warto odczytać na nowo sens takich pojęć, jak „nauczanie”, „kształcenie”, „uczenie się”, żeby lepiej zrozumieć relacje zachodzące między nimi. To ponowne odczytywanie dokonuje się w prezentowanej publikacji w kontekście swoistości myślenia i działania pedagogicznego, za którą opowiada się autor, i której broni.

Czytelnik w trakcie lektury ma rzadko spotykaną szansę zrozumienia, w czym tkwi tożsamość pedagogiki jako nauki. Jest to o tyle ważne, że współcześnie obserwujemy silną tendencję do redukowania dyscypliny pedagogika do jakiejś części psychologii, socjologii, filozofii itp. Pedagodzy przejawiają dziwną skłonność do

* Prof. dr hab. Henryk Mizerek, Uniwersytet Warmińsko-Mazurski w Olsztynie, Wydział Nauk Społecznych, Instytut Nauk Pedagogicznych, Katedra Pedagogiki Społecznej i Metodologii Badań Edukacyjnych; e-mail: mizerek@uwm.edu.pl. 
bezrefleksyjnego przejmowania języka, teorii i metod innych dyscyplin naukowych. Wskutek tego w tekstach pedagogicznych aż roi się od „-izmów”, a sama pedagogika i jej przedstawiciele tracą z pola widzenia obowiązek tworzenia wiedzy, która będzie społecznie „zdrowa” i posłuży do rozwiązywania palących problemów praktyki edukacyjnej.

Monografia D. Bennera wyróżnia się bardzo starannie przemyślaną strukturą i układem treści. Tworzy ją sześć rozdziałów. Pierwszy został zaty tułowany Lekcje mistrzów - zhistorii europejskiego i amerykańskiego dyskursu pedagogicznego. Autor na podstawie trafnie dobranych źródeł przeprowadza w nim wielostronne analizy relacji między doświadczeniem a wiedzą oraz uczeniem się a nauczaniem. Tytułowe „lekcje” to kolejno: interpretacja metafory jaskini z Platońskiego Państwa; lekcja geometrii, której udzielił Sokrates w dialogu Menon; relacja między „nauczalnością” i „wyuczalnością” w ujęciu Arystotelesa; lekcja nowożytnej fizyki, którą przeprowadził w Emilu J.J. Rousseau; wskazówki J. Fichtego na temat dydaktycznego konstruowania trójkąta; Herbartowska teoria nauczania wychowującego i w końcu koncepcja dydaktyki jednolitej naszkicowana przez J. Dewey’a w Demokracji i wychowaniu.

Pierwszy rozdział tworzy fundament zarysu ogólnej dydaktyki nauki, który w swojej książce szkicuje D. Benner. W następnych dochodzą do niego nowe elementy. Niemniej przypomniane i rozwinięte przez niego dwie kategorie: „nauczalność" i „wyuczalność” stanowią główną - jak to określa D. Benner - „figurę myślową", porządkującą całość opracowania. Wyprowadzona $\mathrm{z}$ alegorii jaskini teza, że wychowanie należy utożsamiać $\mathrm{z}$ wpływem edukacyjnym polegającym na skłanianiu uczącego się do zmiany we własnym kierunku patrzenia i wspieraniu go w tym, żeby wytworzył więź (samo)kształceniową między sobą a światem, znajduje swoje uzasadnienie w bardzo wielu - także współczesnych - koncepcjach pedagogicznych.

Zapoczątkowane w „lekcjach mistrzów” wątki są kontynuowane w rozdziale drugim - załytułowanym Podstawowe rozróżnienia. D. Benner analizuje w nim relacje zachodzące między dwiema parami kategorii - wychowaniem a (samo) kształceniem oraz nauczaniem a uczeniem się. W tym kontekście wskazuje na wielorakie konsekwencje ich bezrefleksyjnego i bezkrytycznego traktowania w trakcie koncypowania teorii pedagogicznych, prowadzenia badań edukacyjnych i kształcenia nauczycieli.

Rozdział trzeci ma - w moim odbiorze - fundamentalne znaczenie dla zrozumienia całości dzieła D. Bennera. Zostały w nim podjęte dogłębne analizy kategorii, które pojawiły się już wcześniej, lecz teraz odniesiono je do wybranych paradygmatów nauki i tworzonych w ich obrębie typów wiedzy. Autorski dobór paradygmatów i sposób ich dydaktycznego odczytania okazał się bardzo owocny z punktu widzenia zadań postawionych przez D. Bennera Zarysowi ogólnej dydaktyki nauki. Przeprowadzona w tym rozdziale konceptualizacja ma charakter uniwersalny, przez co całe dzieło zyskuje na wartości. Za wartościowe uznaję nie 
tylko pożytek płynący dla myślenia o pracy nauczycieli i ich kształceniu, lecz także metodologii badań edukacyjnych.

Szczególnie cenne są analizy odnoszące się do kwestii epistemologicznych i metodologicznych badań nad edukacją. D. Benner zaproponował konceptualizację, która - jak sądzę - uzupełnia i znacznie poszerza znaną i powszechnie wykorzystywaną w pedagogice socjologiczną klasyfikację paradygmatów. Sformułowali ją Gibson Burrel i Gareth Morgan (1979). Lektura recenzowanej pracy przekonuje, że konceptualizacja D. Bennera jest bardziej użyteczna do analizowania istniejących już teorii i projektowania pedagogicznych badań nad edukacją niż propagowane - także w polskich podręcznikach pedagogiki i metodologii - typologie paradygmatów naukowych. Na uwagę zasługuje zwłaszcza zachęta D. Bennera do - jak pisze - „pragmatycznego obchodzenia się” z wielością paradygmatów naukowych i tworzonych $w$ ich ramach typów wiedzy. Podzielam pogląd autora, że uczestniczenie w „wojnie paradygmatów” jest dzisiaj pozbawione sensu. Można jednak - i trzeba - traktować wiedzę wytwarzaną w każdym z nich jako pomoc do projektowania działania pedagogicznego i diagnozowania wyników procesów (samo)kształcenia.

Treści zamieszczone w rozdziale czwartym są wynikiem analiz kierunków rozwoju XX-wiecznej pedagogiki niemieckiej. Stanowią one bardzo pouczającą lekcję także i dla polskich czytelników - tym bardziej że nasza wiedza na ten temat jest raczej skromna. Znacznie bardziej popularne stały się współcześnie koncepcje wytwarzane na gruncie anglosaskim. Lekturę tej części dzieła ułatwia przyjęty przez autora sposób narracji i logika wywodu.

Rozdział piąty został zatytułowany Elementy ogólnej dydaktyki nauki. Stanowi on swoistego rodzaju pedagogiczne zwieńczenie poruszanych wcześniej wątków. Za niezwykle wartościowe z teoretycznego i praktycznego punktu widzenia należy uznać zamieszczone na początku tego rozdziału przykłady metodycznych pytań kierunkowych, które wynikają z ośmiu paradygmatów naukowych i typów wiedzy generowanych w ich obrębie. D. Benner koncentruje się w swoich analizach na zaletach każdego $\mathrm{z}$ nich w perspektywie procesów (samo)kształcenia, unikając świadomie roli adwokata czy stronnika któregokolwiek z nich. Równie interesujące i wartościowe są zamieszczone nieco dalej interpretacje trzech triad - szkolnej, dydaktycznej i ewaluacyjnej.

Kontynuacją poprzednich rozważań jest rozdział szósty, zatytułowany Przykłady. D. Benner przedstawił w nim pięć przykładów lekcji szkolnych, w których prowadzący odwołują się do co najmniej dwóch typów wiedzy.

Pierwszy przykład traktuje o starożytnej wersji twierdzenia Pitagorasa i jej nowoczesnej reinterpretacji. Drugi dotyczy lekcji fizyki. Trzeci przykład został zaczerpnięty z nauczania biologii i odnosi się do kontrowersyjnej teorii ewolucji Darwina. Czwarty przykład autor zaczerpnął z własnych doświadczeń w zakresie konstruowania zadań testowych uwzględniających różne typy wiedzy moralno-etycznej. W piątym przykładzie rozważono, jak można połączyć lekcje wiedzy 
obywatelskiej na temat ustawy zasadniczej Republiki Federalnej Niemiec z dyskusją historyczną na temat powojennych dziejów państwowości niemieckiej. Treści tego rozdziału stanowią znakomity dowód na to, że można nadać głęboki, praktyczny sens teoretycznym koncepcjom pedagogicznej praxis.

Recenzowaną publikację zamyka rozdział pt. Perspektywy dotyczace przyszłości dydaktyki nauki. Rozważania w nim zamieszczone odnoszą się do przyszłości dydaktyki nauki rozumianej przez D. Bennera jako sedno dydaktyki szkoły wyższej. Treści tego rozdziału stanowią ważny głos w dyskusji nad przemianami dokonującymi się w koncepcjach kształcenia uniwersyteckiego - m.in. zwrotu polegającego na odejściu od nauczania na rzecz uczenia (ang. shift from teaching to learning) i zwrotu konstruktywistycznego (ang. constructive alignment). Autor dostarcza mocnych argumentów przeciwko pojawiającym się obecnie trendom w dydaktyce szkoły wyższej i wskazuje na negatywne konsekwencje, które niesie ze sobą bezrefleksyjne i biurokratycznie sterowane wprowadzanie ich w życie. Równocześnie postuluje pluralizację zarówno badań naukowych, jak i nauczania akademickiego.

Po ogólnym zaprezentowaniu pozwolę sobie sformułować kilka uwag szczegółowych odnośnie recenzowanej publikacji. Jak trafnie zauważył Dariusz Stępkowski, tłumacz Zarysu ogólnej dydaktyki nauki, książka D. Bennera „jak średniowieczna katedra pnie się w górę i wystrzeliwuje w stronę nieba, gdzie zasiada Mądrość" (s. 9). Słowa te odnoszą się w moim przekonaniu zarówno do treści, jak i konstrukcji formalnej dzieła. Przychodzi mi na myśl metafora monumentalnej budowli projektu Antoniego Gaudiego (1852-1926) - bazyliki Sagrada Familia w Barcelonie. Jej wznoszenie - rozpoczęte przed 138 laty - nadal trwa. Sądzę, że nie będzie żadnej przesady w porównaniu do niej dzieła D. Bennera. Zachowując szacunek dla tradycji i źródeł, z których wyrasta myślenie i działanie pedagogiczne, tworzy ono jednocześnie bardzo nowatorski w treści i formie projekt, który pozostaje niedokończony. Na przekór powszechnej dzisiaj manierze „chodzenia na skróty”, negowania potrzeby gruntownego, wszechstronnego wykształcenia pedagogów (wielu wśród nich przypomina - niestety - ludzi z Platońskiej metafory jaskini, tzn. kajdaniarzy skutych kajdanami na rękach i nogach i wpatrujących się w ścianę na wprost), Autor apeluje o „zmianę kierunku patrzenia”. Dzieło Bennera nie jest dokończone w tym sensie, że nie tylko otwiera nowe perspektywy dla pedagogiki, lecz wskazuje na miejsca, w których pojawiać się muszą liczne aporie i irytacje. Dostarcza przy tym wielu inspirujących impulsów do poszukiwania rozwiązań dla problemów, które niesie ze sobą teraźniejszość i nieznana nam jeszcze przyszłość.

Wartości Zarysu ogólnej dydaktyki nauki można doszukiwać się w wielu obszarach. Wspomnę tylko o niektórych $\mathrm{z}$ nich. W moim przekonaniu są one najważniejsze z punktu widzenia polskiego odbiorcy.

Najpierw zwrócę uwagę na stronę redakcyjną opracowania, a w szczególności na układ treści i logikę wywodu. W tekście nie ma zbędnych dygresji i rozwlekłych wyjaśnień. Tym, co się rzuca się w oczy, jest rzadko spotykana dyscyplina 
intelektualna autora i zabiegi redakcyjne ułatwiające recepcję skomplikowanych treści. Całość monografii stanowi zwartą i przemyślaną konstrukcję.

Wielką zaletą dzieła D. Bennera jest szeroki zakres eksploracji skierowanych na odkrycie podstawowych kategorii pedagogicznych i relacji między nimi. Tak dla adeptów pedagogiki, jak i dla osób uprawiających tę dyscyplinę od dawna jest to znakomita, mistrzowska lekcja.

Sposób, w jaki autor prowadzi badania i prezentuje ich wyniki, może być znakomitym przykładem korzystania w pedagogice $\mathrm{z}$ dorobku innych nauk o człowieku (w tym przypadku szczególnie filozofii). Tym, co go wyróżnia, jest nieredukowanie pedagogiki do filozofii wychowania. Przekonuje mnie teza D. Bennera o konieczności zachowania tożsamości pedagogiki przez m.in. translację kategorii powstałych w obszarze psychologii, socjologii, filozofii i innych nauk o człowieku na tradycyjny język myślenia i działania pedagogicznego.

Inną zasługą autora jest przedstawiona w książce nowatorska konceptualizacja paradygmatów wiedzy naukowej i wskazanie na możliwości jej wykorzystania w projektowaniu procesów (samo)kształcenia i badaniu ich efektywnosci. Konceptualizacja ta otwiera nowe perspektywy dla projektowania i prowadzenia pedagogicznych badań nad edukacją. Generalnie można powiedzieć, że w empirycznych badaniach pedagogicznych z rzadka uobecnia się refleksja epistemologiczna i świadomość typów wiedzy naukowej - i to nie tylko w Polsce. W dalszym ciągu akcentuje się kwestie „poprawności metodologicznej” zredukowanej do technicznych aspektów badania. Metodologię badań zwykło opisywać się w odniesieniu wyłącznie do metodyki - podobnie jak to się dzieje w naukach przyrodniczych. W tym kontekście D. Benner słusznie się domaga, żeby dyskusję nad uzyskanymi wynikami prowadzić z perspektywy wielu paradygmatów wiedzy naukowej, które zasługują na komplementarne traktowanie.

Wspomniany powyżej wątek metodologii badań pedagogicznych jest jedną z wielu możliwych, celowo „niedomkniętych” przez autora kwestii domagających się rozstrzygnięcia w przyszłości. Innym niezmiernie ważnym wątkiem jest konieczność rewizji przyjętych w praktyce dydaktycznej koncepcji kształcenia nauczycieli. W Polsce, biorąc pod uwagę historyczny i społeczny kontekst problemu, sprawa ta jest szczególnie skomplikowana.

Ostatnim zagadnieniem szczegółowym, na które chciałbym zwrócić uwagę, jest kwestia dydaktyki szkoły wyższej. D. Benner sygnalizuje ją w ostatnim rozdziale, zamykającym opracowanie. Z polskiej perspektywy zmiana praktyki kształcenia akademickiego wydaje się rodzajem misji niewykonalnej. Dzieje się tak z bardzo wielu powodów, które w tym miejscu trudno przeanalizować. Jednak argumenty D. Bennera i przykład dyskusji toczonej w Niemczech na ten temat mogą być cennym wsparciem dla rodzącej się także Polsce „wspólnoty pedagogicznego niepokoju”. Przedmiotem niepokoju są m.in. skutki neoliberalnych reform w szkolnictwie wyższym i powody, dla których uznawane jest za jedynie słuszne myślenie 
o efektach uczenia się w "gorsecie” stworzonym przez taksonomię Benjamina S. Blooma (1913-1999).

Książka powinna zainteresować liczne grono czytelników. W pierwszym rzędzie są nimi akademicy zajmujący się edukacją. Kolejną grupą są studenci i doktoranci realizujący projekty badawcze $\mathrm{w}$ ramach prac promocyjnych. Z pewnością zainteresuje ona również bardzo wielu refleksyjnych nauczycieli poszukujących intelektualnych narzędzi dla nadania znaczenia i odkrycia sensu tego, co stanowi treść ich zawodowej codzienności.

\section{Bibliografia}

Burrel G., Morgan G. (1979). Sociological Paradigms and Organizational Analysis. London and Exter: NH. Heinemann. 